\section{Factors associated with cesarean sections in a public hospital in Rio de Janeiro, Brazil}

\author{
Fatores associados à realização de cesáreas \\ em uma maternidade pública do Município \\ do Rio de Janeiro, Brasil
}

\author{
Eleonora D'Orsi 1 \\ Dora Chor 2 \\ Karen Giffin ${ }^{2}$ \\ Antonia Angulo-Tuesta 2,3 \\ Gisele Peixoto Barbosa 2,4 \\ Andréa de Sousa Gama 2,5 \\ Ana Cristina Reis 2,6
}

\section{Introduction}

Brazil has one of the world's highest cesarean section rates. Contributing factors include the organization of obstetric practice, physicians' attitudes, and women's preferences and decisions. This study aimed to identify factors associated with cesarean sections in a public maternity hospital in Rio de Janeiro. A case-control study was conducted with 231 cesarean sections (cases) and 230 vaginal deliveries (controls). $\mathrm{Hi}$ erarchical logistic regression analysis was performed, based on a conceptual model. Factors associated with increased odds of cesarean section were: primiparity; mother's age 20-34; last birth by cesarean; cervical dilatation $<3 \mathrm{~cm}$ at admission; patient request; daytime birth; male attending obstetrician; obstetrician on duty for more than 24 hours a week; obstetrician with private practice; gestational hypertension; noncephalic presentation; and gestational age $>41$ weeks. Factors associated with lower odds of cesarean were: gestational age $<37$ weeks; leaving home with signs of labor, use of oxytocin; and amniotomy. In this hospital, interventions aimed to modify the above-mentioned factors can help lower the cesarean rate.

Cesarean Section; Parturition; Maternity come 6 .
Brazil has one of the world's highest cesarean section rates in the world (38\% of live births in 2000) 1 , surpassed only by Chile, with $42 \%$ in 19992 . Recently, a slight downward trend in the cesarean rate has been observed in the Brazilian public sector, from $32 \%$ in $1994-1997$ to $25 \%$ in 20013 .

In Brazil, higher socioeconomic status is associated with increased probability of a cesarean section. Thus, the cesarean rate is higher in more developed regions like the Southeast (45\%), South (40\%), and Central-West (43\%) than in the less developed North (27\%) and Northeast (25\%) 4 . The rate is also higher in private hospitals $(70 \%)$ as compared to public (32\%) 5 and in women with more schooling and higher in-

Another aspect of inadequate use of cesareans in Brazil is the difficult access to hospital care (particularly in poorer regions of the country) 7 , but even in developed metropolitan areas like Rio de Janeiro the excessive use of cesarean sections coexists with its absence when clearly indicated 8 .

Studies suggest several factors related to the high cesarean rate, including obstetrician's convenience with this programmed intervention ${ }^{9}$, physicians' lack of training for unexpected situations during delivery 10 , lack of integration between prenatal and childbirth services, 
and the hospital shift system, which does not allow women to remain in labor from one shift to the next 11 .

Contrary to allegations by some obstetricians, recent studies, including the Latin American Study on Cesarean Sections (ELAC) 14, show a declared preference for vaginal birth among Brazilian women (about 70\%) 5,12,13. This study shows faster recovery and a less painful postpartum as the principal reasons for this preference, and the absence of contractions as the principal advantage of a cesarean. Most women feel that a cesarean should be performed only when there is no alternative (due to serious illness of the woman or risk to the fetus) 14 .

This study focuses on the association between cesarean sections and factors related to the patient, physicians, and organization of obstetric practice. Brazilian epidemiological studies on these three dimensions are scarce 11,15. We thus aim to contribute to a more detailed knowledge of the mechanisms leading to cesarean sections in the selected maternity hospital.

\section{Methodology}

\section{$\underline{\text { Study design }}$}

A case-control study was conducted from October 1998 to March 1999 in a public maternity hospital in the city of Rio de Janeiro, where cesarean deliveries were classified as cases and vaginal deliveries as controls.

The sample was planned to include 225 cases and 225 controls 16 . With $80 \%$ power and a $5 \%$ significance level, this number was sufficient to detect an odds ratio (OR) of $\geq 2.0$ for an exposure among controls ranging proportionally from $15 \%$ to $70 \% 16$. All cesarean deliveries occurring on the day prior to the interviews, plus a systematic sample of approximately $50 \%$ of the vaginal deliveries chosen from the hospital's birth registry, were included in the study. Exclusion criteria were mother's age $<16$ years, gestational age $<28$ weeks, stillbirths, and deliveries by obstetric nurses (since they performed only vaginal deliveries).

\section{Data sources}

Data were collected in interviews with postpartum mothers in the infirmary, from 24 to 48 hours after birth. Interviews with physicians and review of patient charts were also performed. The study was approved by the institutional review board, and informed consent was obtained from participants before interviews.
Information was collected from the women on socioeconomic and demographic characteristics, reproductive history, prenatal care, adverse gestational or labor events, preference for cesarean, request for cesarean, women's perception of signs of labor when leaving home for the hospital, and tubal sterilization. In the review of medical charts, admission characteristics, labor management, and time of birth were recorded. In the interviews with obstetricians, information was taken on gender, age, year of graduation, work in private clinics, and number of hours per week on hospital duty.

\section{Data analysis}

According to the conceptual model created and tested by Freitas 11, the factors that influence type of delivery can be grouped into hierarchical levels of influence, numbered from 1 to 7 (Figure 1).

An initial bivariate analysis was performed to identify significant associations between type of delivery (cesarean vs. vaginal) and a series of independent variables. Odds ratios were estimated only for variables showing significant association with type of delivery $(p<0.05)$.

Multivariate logistic regression analysis was performed with SPSS, version 8.0 (SPSS Inc., Chicago, USA). Variables were entered into the model manually, according to the hierarchical order established by the conceptual model 11 . A model was fitted for each level. In the first model, first-order variables that were significant in the bivariate analysis were included. In the second model, only first-order variables with a significance of 0.10 or less (measured by the Wald test) remained, along with significant variables from the second level. This procedure was repeated until the last level. The model's explanatory power at each level was evaluated by measuring the increase in the value of $-2 \mathrm{log}$ likelihood (-2LL) with the model's $\chi^{2}$. These statistics allow assessing the effect of intermediate variables on the complex framework of direct and indirect relations among several factors, such as social, demographic, biological, and organization of medical care 11,13,17,18,19,20.

\section{Results}

The final sample size was 461 women (231 cesarean sections and 230 vaginal births). The cesarean rate during the study was approximately $30 \%$. 

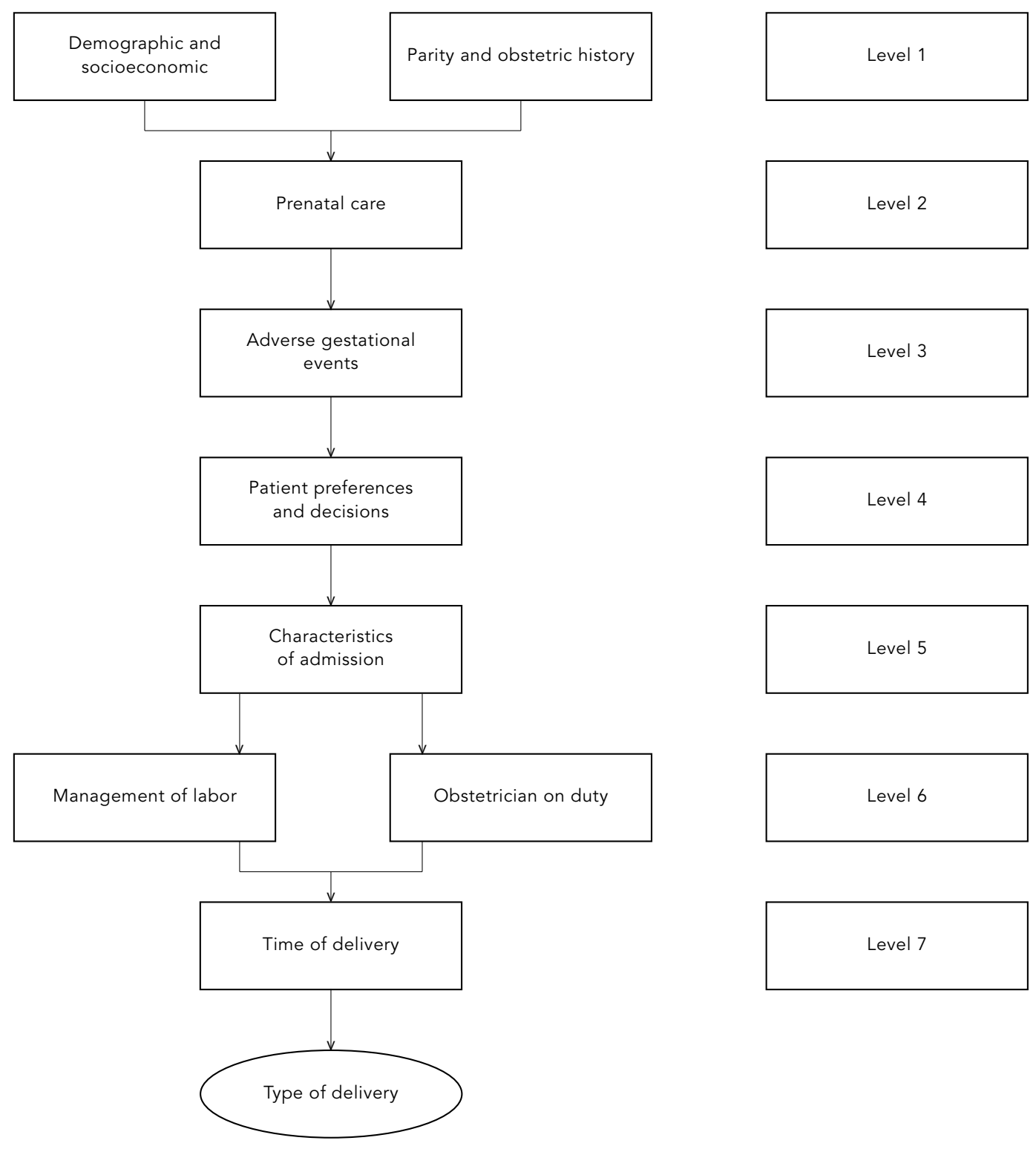

Level 7

\section{Bivariate analysis}

Median age was 24 years for cases (cesarean sections) and 22 for controls (vaginal deliveries). The odds of cesarean were significantly higher for women $>20$ years of age compared to adolescents. Only $1 / 6$ of the women had completed high school or university, and their probability of cesarean was $60 \%$ greater than for women with less schooling. There was a strong association between childbirth/obstetric history and type of delivery. Primiparae and multiparae whose last delivery was by cesarean had significantly higher odds of cesarean than multiparae whose last delivery was vaginal (Table 1, level 1).

As for prenatal characteristics (Table 1, level 2), the odds of cesarean section were significantly higher for women with more than six prenatal visits, who had begun prenatal care in 
Demographic and socioeconomic characteristics, parity, and obstetric history, prenatal care, adverse gestational events, and patient preferences and decisions by type of delivery. Public maternity hospital, Rio de Janeiro, Brazil, 1998/1999.

\begin{tabular}{|c|c|c|c|c|c|c|}
\hline & \multicolumn{2}{|c|}{ Cesarean sections } & \multicolumn{2}{|c|}{ Vaginal births } & \multirow{2}{*}{$\mathrm{OR}^{*}$} & \multirow{2}{*}{$95 \% \mathrm{Cl}$} \\
\hline & $n$ & $\%$ & $n$ & $\%$ & & \\
\hline \multicolumn{7}{|c|}{$\begin{array}{l}\text { Level } 1 \text { - Demographic and socioeconomic } \\
\text { characteristics, parity, and obstetric history }\end{array}$} \\
\hline \multicolumn{7}{|l|}{ Age (years) } \\
\hline $16-19$ & 39 & 17.2 & 69 & 30.3 & 1.0 & \\
\hline $20-34$ & 158 & 69.6 & 141 & 61.8 & 2.0 & $1.3-3.1$ \\
\hline$\geq 35$ & 30 & 13.2 & 18 & 7.9 & 3.0 & $1.5-6.0$ \\
\hline Total & 227 & 100.0 & 228 & 100.0 & & \\
\hline \multicolumn{7}{|l|}{ Schooling } \\
\hline$<$ Secondary & 133 & 57.6 & 145 & 63.0 & 1.0 & \\
\hline Secondary & 53 & 22.9 & 54 & 23.5 & 1.0 & $0.7-1.7$ \\
\hline$\geq$ University & 45 & 19.5 & 31 & 13.5 & 1.6 & $0.9-2.6$ \\
\hline Total & 231 & 100.0 & 230 & 100.0 & & \\
\hline \multicolumn{7}{|l|}{ Parity/obstetric history } \\
\hline Last delivery vaginal & 37 & 16.0 & 124 & 53.9 & 1.0 & \\
\hline Primiparae & 97 & 42.0 & 85 & 37.0 & 3.8 & 2.4-6.1 \\
\hline Last delivery cesarean & 97 & 42.0 & 21 & 9.1 & 15.5 & $8.5-28.1$ \\
\hline Total & 231 & 100.0 & 230 & 100.0 & & \\
\hline \multicolumn{7}{|l|}{ Level 2 - Prenatal care } \\
\hline \multicolumn{7}{|l|}{ Number of visits } \\
\hline 0 to 5 & 100 & 43.3 & 127 & 55.2 & 1.0 & \\
\hline$\geq 6$ & 131 & 56.7 & 103 & 44.8 & 1.6 & $1.1-2.3$ \\
\hline Total & 231 & 100.0 & 230 & 100.0 & & \\
\hline \multicolumn{7}{|l|}{ Trimester of initiation } \\
\hline $2^{\text {nd }}$ or 3 rd & 83 & 35.9 & 100 & 43.5 & 1.0 & \\
\hline $1 \mathrm{st}$ & 137 & 59.3 & 105 & 45.7 & 1.6 & $1.1-2.3$ \\
\hline No prenatal care & 11 & 4.8 & 25 & 10.9 & 0.5 & $0.2-1.1$ \\
\hline Total & 231 & 100.0 & 230 & 100.0 & & \\
\hline \multicolumn{7}{|c|}{ Prenatal and delivery at same hospital } \\
\hline No & 169 & 73.2 & 184 & 80.0 & 1.0 & \\
\hline Yes & 51 & 22.1 & 22 & 9.6 & 2.5 & $1.5-4.3$ \\
\hline No prenatal care & 11 & 4.8 & 24 & 10.4 & 0.5 & $0.2-1.1$ \\
\hline Total & 231 & 100.0 & 230 & 100.0 & & \\
\hline \multicolumn{7}{|c|}{ Level 3 - Adverse gestational events } \\
\hline \multicolumn{7}{|l|}{ Hypertension } \\
\hline No & 114 & 49.4 & 189 & 82.2 & 1.0 & \\
\hline Yes & 117 & 50.6 & 41 & 17.8 & 4.7 & $3.1-7.2$ \\
\hline Total & 231 & 100.0 & 230 & 100.0 & & \\
\hline \multicolumn{7}{|l|}{ 3rd trimester bleeding } \\
\hline No & 217 & 93.9 & 227 & 98.7 & 1.0 & \\
\hline Yes & 14 & 6.1 & 3 & 1.3 & 4.9 & 1.4-17.2 \\
\hline Total & 231 & 100.0 & 230 & 100.0 & & \\
\hline \multicolumn{7}{|l|}{ Loss of amniotic fluid } \\
\hline No & 210 & 90.9 & 215 & 93.5 & 1.0 & \\
\hline Yes & 21 & 9.1 & 15 & 6.5 & 1.4 & $0.7-2.8$ \\
\hline Total & 231 & 100.0 & 230 & 100.0 & & \\
\hline
\end{tabular}

(continues) 


\begin{tabular}{|c|c|c|c|c|c|c|}
\hline \multirow[t]{2}{*}{ Cesarean sections } & \multicolumn{2}{|c|}{ Vaginal births } & \multicolumn{2}{|c|}{$\mathrm{OR}^{*}$} & \multirow[t]{2}{*}{$95 \% \mathrm{Cl}$} & \\
\hline & n & $\%$ & $\mathrm{n}$ & $\%$ & & \\
\hline \multicolumn{7}{|l|}{ Fetal distress } \\
\hline No & 217 & 95.6 & 225 & 98.7 & 1.0 & \\
\hline Yes & 10 & 4.4 & 3 & 1.3 & 3.4 & $0.9-12.6$ \\
\hline Total & 227 & 100.0 & 228 & 100.0 & & \\
\hline \multicolumn{7}{|c|}{ Level 4 - Patient preferences and decisions } \\
\hline \multicolumn{7}{|l|}{ Wanted a cesarean } \\
\hline No & 141 & 61.0 & 185 & 80.4 & 1.0 & \\
\hline Yes & 83 & 35.9 & 42 & 18.3 & 2.6 & $1.7-4.0$ \\
\hline Didn't know & 7 & 3.0 & 3 & 1.3 & 3.1 & $0.8-12.1$ \\
\hline Total & 231 & 100.0 & 230 & 100.0 & & \\
\hline \multicolumn{7}{|c|}{ Requested a cesarean } \\
\hline No & 193 & 83.5 & 202 & 87.8 & 1.0 & \\
\hline Yes & 38 & 16.5 & 28 & 12.2 & 1.4 & $0.8-2.4$ \\
\hline Total & 231 & 100.0 & 230 & 100.0 & & \\
\hline \multicolumn{7}{|l|}{ Tubal sterilization } \\
\hline No & 208 & 90.4 & 223 & 97.0 & 1.0 & \\
\hline Yes & 22 & 9.6 & 7 & 3.0 & 3.4 & $1.4-8.1$ \\
\hline Total & 230 & 100.0 & 230 & 100.0 & & \\
\hline \multicolumn{7}{|c|}{$\begin{array}{l}\text { Women's perception of signs of labor } \\
\text { when leaving home }\end{array}$} \\
\hline No & 63 & 27.3 & 12 & 5.2 & 1.0 & \\
\hline Yes & 168 & 72.7 & 218 & 94.8 & 0.1 & $0.0-0.3$ \\
\hline Total & 231 & 100.0 & 230 & 100.0 & & \\
\hline
\end{tabular}

* OR = odds of cesarean section/odds of vaginal delivery. Note: associations with $\mathrm{p}<0.05$ in bold.

the first trimester, or who had prenatal care and delivery in the same hospital. Concerning adverse gestational events (Table 1, level 3), there was a significant association between thirdtrimester hypertension or bleeding and cesarean section.

Most participants reported not wanting a cesarean (Table 1, level 4). Wanting or requesting a cesarean was associated with surgical birth. Tubal sterilization also increased the odds of a cesarean, while leaving home with signs of labor showed significantly lower odds of cesarean. Various admission characteristics (Table 2, level 5) were significantly associated with cesareans. The strongest associations were for cervical dilatation $<3 \mathrm{~cm}$ and non-cephalic fetal presentation. In the management of labor (Table 2, level 6), use of oxytocin and amniotomy showed significantly lower odds of cesarean section. As for the obstetrician's characteristics, male gender, $>20$ years since graduation, private practice, and more than 24 hours/week on duty increased the odds of cesarean. At level 7 there was a significant association between type of delivery and time of day, with cesarean sections more frequent from 9:00 am to 2:59 pm (Table 2).

\section{Multivariate analysis}

The first characteristics included in the model were woman's age and educational level (Table 3). After adjustment for parity/obstetric history, women $>35$ years of age showed an OR of 7.3 for cesarean section (95\%CI: $2.9-18.5$ ) as compared to younger women. In addition, a persistently strong influence was shown for both first delivery and previous cesarean: primiparae showed an OR of 6.7 (95\%CI: 3.8-11.9), and multiparae whose last delivery was cesarean had an OR of 19.3 (95\%CI: 10.2-36.5) as compared to those whose last delivery was vaginal.

At level 2 (Table 3), the positive association between the number of prenatal visits and odds of cesarean disappeared when prenatal variables, age group, and obstetric history were included in the model. However, initiating prenatal care in the first trimester and having pre- 
Characteristics of admission, management of labor, attending obstetrician, and time of decision by type of delivery. Public hospital, Rio de Janeiro, Brazil, 1998/1999.

\begin{tabular}{|c|c|c|c|c|c|c|}
\hline & \multicolumn{6}{|c|}{ Public hospital } \\
\hline & \multicolumn{2}{|c|}{ Cesarean section } & \multicolumn{2}{|c|}{ Vaginal delivery } & \multirow{2}{*}{$O R^{\star}$} & \multirow[t]{2}{*}{$95 \% \mathrm{Cl}$} \\
\hline & $\mathrm{n}$ & $\%$ & $\mathrm{n}$ & $\%$ & & \\
\hline \multicolumn{7}{|c|}{ Level 5 - Characteristics of hospital admission } \\
\hline \multicolumn{7}{|l|}{ Time of admission (hours) } \\
\hline $22: 00$ to $05: 59$ & 55 & 25.9 & 80 & 37.0 & 1.0 & \\
\hline $06: 00$ to $17: 59$ & 119 & 56.1 & 107 & 49.5 & 1.6 & $1.0-2.5$ \\
\hline $18: 00$ to $21: 59$ & 38 & 17.9 & 29 & 13.4 & 1.9 & $1.0-3.4$ \\
\hline Total & 212 & 100.0 & 216 & 100.0 & & \\
\hline \multicolumn{7}{|l|}{ Cervical dilatation } \\
\hline$\geq 3 \mathrm{~cm}$ & 54 & 24.3 & 172 & 76.4 & 1.0 & \\
\hline$<3 \mathrm{~cm}$ & 168 & 75.7 & 53 & 23.6 & 10.1 & $6.5-15.6$ \\
\hline Total & 222 & 100.0 & 225 & 100.0 & & \\
\hline \multicolumn{7}{|l|}{ Status of membranes } \\
\hline Ruptured & 55 & 24.2 & 75 & 32.9 & 1.0 & \\
\hline Intact & 172 & 75.8 & 153 & 67.1 & 1.5 & $1.0-2.3$ \\
\hline Total & 227 & 100.0 & 228 & 100.0 & & \\
\hline \multicolumn{7}{|l|}{ Gestational age (weeks) } \\
\hline $37-40$ & 132 & 59.5 & 144 & 65.8 & 1.0 & \\
\hline$<37$ & 57 & 52.7 & 61 & 27.9 & 1.0 & $0.7-1.6$ \\
\hline $41-43$ & 33 & 14.9 & 14 & 6.4 & 2.6 & $1.3-5.0$ \\
\hline Total & 222 & 100.0 & 219 & 100.0 & & \\
\hline \multicolumn{7}{|l|}{ Fetal presentation } \\
\hline Cephalic & 203 & 89.4 & 226 & 99.1 & 1.0 & \\
\hline Other (majority breech) & 24 & 10.6 & 2 & 0.9 & 13.4 & $3.1-57.2$ \\
\hline Total & 227 & 100.0 & 228 & 100.0 & & \\
\hline \multicolumn{7}{|c|}{$\begin{array}{l}\text { Level } 6 \text { - Management of labor and } \\
\text { characteristics of attending obstetrician }\end{array}$} \\
\hline \multicolumn{7}{|l|}{ Use of oxytocin } \\
\hline No & 196 & 86.0 & 136 & 60.7 & 1.0 & \\
\hline Yes & 32 & 14.0 & 88 & 39.3 & 0.3 & $0.1-0.4$ \\
\hline Total & 228 & 100.0 & 224 & 100.0 & & \\
\hline \multicolumn{7}{|l|}{ Amniotomy } \\
\hline No & 183 & 85.5 & 139 & 63.8 & 1.0 & \\
\hline Yes & 31 & 14.5 & 79 & 36.2 & 0.3 & $0.2-0.5$ \\
\hline Total & 214 & 100.0 & 218 & 100.0 & & \\
\hline \multicolumn{7}{|l|}{ Obstetrician's gender } \\
\hline Female & 62 & 27.6 & 116 & 51.3 & 1.0 & \\
\hline Male & 163 & 72.4 & 110 & 48.7 & 2.8 & $1.8-4.1$ \\
\hline Total & 225 & 100.0 & 226 & 100.0 & & \\
\hline \multicolumn{7}{|c|}{ Time since graduation (years) } \\
\hline$<7$ & 41 & 21.8 & 57 & 33.3 & 1.0 & \\
\hline $7-19$ & 58 & 30.9 & 48 & 28.1 & 1.7 & $1.0-2.9$ \\
\hline$\geq 20$ & 89 & 47.3 & 66 & 38.6 & 1.9 & $1.1-3.1$ \\
\hline Total & 188 & 100.0 & 171 & 100.0 & & \\
\hline
\end{tabular}




\begin{tabular}{|c|c|c|c|c|c|c|}
\hline \multirow{3}{*}{ Public hospital } & \multirow{2}{*}{\multicolumn{2}{|c|}{ Cesarean section }} & \multirow{2}{*}{\multicolumn{2}{|c|}{ Vaginal delivery }} & \multirow{3}{*}{$O R^{*}$} & \multirow{3}{*}{$95 \% \mathrm{Cl}$} \\
\hline & & & & & & \\
\hline & $n$ & $\%$ & $n$ & $\%$ & & \\
\hline \multicolumn{7}{|l|}{ Private practice } \\
\hline No & 91 & 48.4 & 100 & 58.5 & 1.0 & \\
\hline Yes & 97 & 51.6 & 71 & 41.5 & 1.5 & $1.0-2.3$ \\
\hline Total & 188 & 100.0 & 171 & 100.0 & & \\
\hline \multicolumn{7}{|c|}{ Hours on duty/week } \\
\hline$<24$ & 92 & 48.9 & 112 & 65.5 & 1.0 & \\
\hline$>24$ & 96 & 51.1 & 59 & 34.5 & 2.0 & $1.3-3.1$ \\
\hline Total & 188 & 100.0 & 171 & 100.0 & & \\
\hline \multicolumn{7}{|c|}{ Level 7 - Time of delivery (hours) } \\
\hline $00: 00$ to $05: 59$ & 31 & 13.7 & 52 & 22.8 & 1.0 & \\
\hline $06: 00$ to $08: 59$ & 8 & 3.5 & 33 & 14.5 & 0.4 & $0.2-1.0$ \\
\hline $09: 00$ to $14: 59$ & 92 & 40.5 & 56 & 24.6 & 2.8 & $1.6-4.8$ \\
\hline $15: 00$ to $23: 59$ & 96 & 42.3 & 87 & 38.2 & 1.9 & $1.1-3.1$ \\
\hline Total & 227 & 100.0 & 228 & 100.0 & & \\
\hline
\end{tabular}

* OR = cesarean section/vaginal delivery.

Note: associations with $p<0.05$ in bold.

natal care and delivery in the same hospital maintained a strong effect on the odds of cesarean section after adjusting for variables at this level and the previous one.

At level 3 (Table 3), hypertension and bleeding continued to be associated with cesarean section. However, because of low precision, third-trimester bleeding was excluded from the model.

At level 4 (Table 3), the OR for cesarean doubled in women who declared a preference for surgical delivery (95\%CI: 1.1-3.4). Women with signs of labor before leaving home had $80 \%$ lower odds of cesarean (OR $=0.2$; 95\%CI: 0.0 0.3 ), after adjusting for statistically significant variables from the previous levels. At this level, performance of tubal sterilization also lost statistical significance.

Time of admission and membrane status (Table 3, level 5) lost statistical significance (shown previously). Cervical dilatation on admission was still one of the variables most strongly associated with type of delivery: women admitted with $<3 \mathrm{~cm}$ dilatation had an OR for cesarean of 8.5 (95\%CI: 4.3-16.6) as compared to those admitted with $\geq 3 \mathrm{~cm}$. Gestational age also remained in the model: gestations $>41$ weeks were more prone to cesarean $(\mathrm{OR}=4.8$; 95\%CI: 1.8-12.8). Fetal presentation was excluded from the model due to the low precision in the estimate of association. Inclusion of cervical dilatation at admission decreased the magnitude of the association between cesare- an section and age group, prenatal care and delivery in the same hospital, and hypertension.

At level 6 (Table 3), the strong inverse association between both oxytocin and amniotomy and cesarean section was maintained. Inclusion of these variables in the model reduced the effects of both age and previous cesarean.

Among the obstetrician's characteristics, the association between male gender and cesarean section was significant $(\mathrm{OR}=2.1 ; 95 \% \mathrm{CI}$ : 0.9 4.7), after adjusting for other physician characteristics and previous levels. Time spent on hospital duty per week ( $>24$ hours) and work in private clinics remained in the model, with a fourfold (95\%CI: 1.5-9.2) and threefold increase (95\%CI: 1.1-10.2) in cesareans, respectively.

Finally, level 7 (Table 3) suggests that if delivery occurred during the morning to early afternoon (09:00 am to 02:59 pm), the OR for a cesarean was 2.7 (95\%CI: 0.9-8.4) as compared to the early morning (00:00 to $05: 59 \mathrm{~h})$. The variables added at each level significantly improved the explanation of the target variable.

\section{Discussion}

This study identified characteristics of patients, physicians, and obstetric care that are potentially related to type of delivery. The strongest predictors of cesarean section were last delivery by cesarean and cervical dilatation of less than $3 \mathrm{~cm}$ at admission. 
Table 3

Hierarchical logistic regression analysis of factors associated with cesarean sections. Public hospital, Rio de Janeiro, Brazil, 1998-1999.

\begin{tabular}{|c|c|c|c|c|c|c|c|}
\hline & $\begin{array}{c}\text { Model } 1 \\
\text { OR }(95 \% \mathrm{Cl})\end{array}$ & $\begin{array}{l}\text { Model } 2 \\
\text { OR }(95 \% \mathrm{Cl})\end{array}$ & $\begin{array}{c}\text { Model } 3 \\
\text { OR }(95 \% \mathrm{Cl})\end{array}$ & $\begin{array}{c}\text { Model } 4 \\
\text { OR }(95 \% \mathrm{Cl})\end{array}$ & $\begin{array}{c}\text { Model } 5 \\
\text { OR }(95 \% \mathrm{Cl})\end{array}$ & $\begin{array}{c}\text { Model } 6 \\
\text { OR }(95 \% \mathrm{Cl})\end{array}$ & $\begin{array}{c}\text { Model } 7 \\
\text { OR }(95 \% \mathrm{CI})\end{array}$ \\
\hline \multicolumn{8}{|l|}{ Level 1} \\
\hline \multicolumn{8}{|l|}{ Schooling } \\
\hline$<$ Secondary & 1.0 & & & & & & \\
\hline Secondary & $1.0(0.6-1.7)$ & & & & & & \\
\hline$\geq$ University & $1.0(0.5-1.9)$ & & & & & & \\
\hline \multicolumn{8}{|l|}{ Age (years) } \\
\hline $16-19$ & 1.0 & 1.0 & 1.0 & 1.0 & 1.0 & 1.0 & 1.0 \\
\hline $20-34$ & $3.2(1.8-5.5)$ & $3.5(2.0-6.2)$ & $3.5(1.9-6.4)$ & $3.7(2.0-6.9)$ & $3.8(1.8-7.9)$ & $3.6(1.3-9.7)$ & $4.0(1.4-11.1)$ \\
\hline$\geq 35$ & $7.3(2.9-18.5)$ & $8.1(3.1-21.1)$ & $7.2(2.5-20.2)$ & $6.8(2.3-19.9)$ & $3.5(1.01-12.5)$ & $3.9(0.8-19.6)$ & $3.8(0.8-19.3)$ \\
\hline \multicolumn{8}{|l|}{ Last delivery } \\
\hline Vaginal & 1.0 & 1.0 & 1.0 & 1.0 & 1.0 & 1.0 & 1.0 \\
\hline Primiparae & $6.7(3.8-11.9)$ & $6.9(3.8-12.4)$ & $8.3(4.3-15.8)$ & $9.1(4.7-17.8)$ & $7.8(3.5-17.5)$ & $6.0(2.3-15.6)$ & $5.4(2.1-13.6)$ \\
\hline Cesarean & $19.3(10.2-36.5)$ & $21.9(11.3-42.6)$ & $27.0(13.1-55.4)$ & $26.5(12.4-56.8)$ & $29.5(11.7-74.4)$ & $14.7(4.7-46.0)$ & $16.7(4.9-56.6)$ \\
\hline \multicolumn{8}{|l|}{ Level 2} \\
\hline \multicolumn{8}{|l|}{ Number of prenatal visits } \\
\hline$\geq 6$ vs. $0-5$ & & $0.7(0.4-1.2)$ & & & & & \\
\hline \multicolumn{8}{|l|}{$\begin{array}{l}\text { Trimester of initiation } \\
\text { of prenatal }\end{array}$} \\
\hline $2^{\text {nd }}$ or $3^{\text {rd }}$ & & 1.0 & & & & & \\
\hline 1 st & & $1.8(1.1-3.1)$ & $1.2(0.7-2.1)$ & & & & \\
\hline $\begin{array}{l}\text { Prenatal and delivery at } \\
\text { same hospital (yes vs. no) }\end{array}$ & & $3.8(1.9-7.3)$ & $2.9(1.4-5.8)$ & $1.9(0.9-4.0)$ & $1.4(0.6-3.3)$ & & \\
\hline \multicolumn{8}{|l|}{ Level 3} \\
\hline Hypertension (yes vs. no) & & & $4.0(2.4-6.6)$ & $3.0(1.7-5.2)$ & $1.9(1.01-3.7)$ & $2.0(0.9-4.7)$ & \\
\hline $\begin{array}{l}\text { 3rd trimester bleeding } \\
\text { (yes vs. no) }\end{array}$ & & & $22.8(4.0-131.8)$ & & & & \\
\hline \multicolumn{8}{|l|}{ Level 4} \\
\hline $\begin{array}{l}\text { Wanted a cesarean } \\
\text { (yes vs. no) }\end{array}$ & & & & $1.9(1.1-3.4)$ & $2.7(1.3-5.6)$ & $2.8(1.1-7.0)$ & $3.4(1.3-8.6)$ \\
\hline $\begin{array}{l}\text { Tubal sterilization } \\
\text { (yes vs. no) }\end{array}$ & & & & $1.5(0.4-5.0)$ & & & \\
\hline $\begin{array}{l}\text { Patient's perception } \\
\text { of signs of labor when } \\
\text { leaving home (yes vs. no) }\end{array}$ & & & & $0.2(0.0-0.3)$ & $0.2(0.1-0.5)$ & $0.2(0.0-0.6)$ & $0.1(0.0-0.4)$ \\
\hline \multicolumn{8}{|l|}{ Level 5} \\
\hline \multicolumn{8}{|l|}{ Time of admission } \\
\hline $22: 00$ to $05: 59$ & & & & & 1.0 & & \\
\hline $06: 00$ to $17: 59$ & & & & & $0.9(0.4-1.8)$ & & \\
\hline $18: 00$ to $21: 59$ & & & & & $0.8(0.3-2.1)$ & & \\
\hline $\begin{array}{l}\text { Cervical dilatation }<3 \mathrm{~cm} \text { at } \\
\text { admission (yes vs. no) }\end{array}$ & & & & & $8.5(4.3-16.6)$ & $12.8(5.5-29.8)$ & $12.0(5.1-28.3)$ \\
\hline $\begin{array}{l}\text { State of membranes } \\
\text { (intact vs. ruptured) }\end{array}$ & & & & & $1.0(0.5-1.9)$ & & \\
\hline
\end{tabular}

(continues) 


\begin{tabular}{|c|c|c|c|c|c|c|c|}
\hline & $\begin{array}{c}\text { Model } 1 \\
\text { OR }(95 \% \mathrm{Cl})\end{array}$ & $\begin{array}{l}\text { Model } 2 \\
\text { OR }(95 \% \mathrm{Cl})\end{array}$ & $\begin{array}{l}\text { Model } 3 \\
\text { OR }(95 \% \mathrm{Cl})\end{array}$ & $\begin{array}{l}\text { Model } 4 \\
\text { OR }(95 \% \mathrm{Cl})\end{array}$ & $\begin{array}{l}\text { Model } 5 \\
\text { OR }(95 \% \mathrm{Cl})\end{array}$ & $\begin{array}{l}\text { Model } 6 \\
\text { OR }(95 \% \mathrm{Cl})\end{array}$ & $\begin{array}{l}\text { Model } 7 \\
\text { OR }(95 \% \mathrm{Cl})\end{array}$ \\
\hline \multicolumn{8}{|l|}{ Gestational age (weeks) } \\
\hline 37.40 & & & & & 1.0 & 1.0 & 1.0 \\
\hline$<37$ & & & & & $0.6(0.3-1.3)$ & $0.3(0.1-0.9)$ & $0.4(0.1-0.9)$ \\
\hline 41.43 & & & & & $4.8(1.8-12.8)$ & $5.0(1.4-17.2)$ & $4.6(1.3-16.4)$ \\
\hline $\begin{array}{l}\text { Fetal presentation } \\
\text { (other vs. cephalic) }\end{array}$ & & & & & $34.8(5.9-204.7)$ & & \\
\hline \multicolumn{8}{|l|}{ Level 6} \\
\hline Use of oxytocin (yes vs. no) & & & & & & $0.1(0.0-0.3)$ & $0.1(0.0-0.2)$ \\
\hline Amniotomy (yes vs. no) & & & & & & $0.4(0.2-1.0)$ & $0.4(0.2-1.0)$ \\
\hline $\begin{array}{l}\text { Obstetrician's gender } \\
\text { (male vs. female) }\end{array}$ & & & & & & $2.1(0.9-4.7)$ & $2.2(1.0-5.2)$ \\
\hline \multicolumn{8}{|l|}{$\begin{array}{l}\text { Obstetrician's time since } \\
\text { graduation (years) }\end{array}$} \\
\hline$<7$ & & & & & & 1.0 & \\
\hline 7-19 & & & & & & $0.9(0.3-2.5)$ & \\
\hline$\geq 20$ & & & & & & $1.1(0.3-4.3)$ & \\
\hline Private practice (yes vs. no) & & & & & & $3.3(1.1-10.2)$ & $4.0(1.7-9.5)$ \\
\hline $\begin{array}{l}\text { Hospital duty (> } 24 \text { vs. } \\
<24 \text { h./wk.) }\end{array}$ & & & & & & $3.7(1.5-9.2)$ & $3.5(1.4-8.7)$ \\
\hline \multicolumn{8}{|l|}{ Level 7} \\
\hline \multicolumn{8}{|l|}{ Time of delivery } \\
\hline $00: 00$ to $05: 59$ & & & & & & & 1.0 \\
\hline $06: 00$ to $08: 59$ & & & & & & & $0.4(0.1-1.6)$ \\
\hline $09: 00$ to $14: 59$ & & & & & & & $2.7(0.9-8.4)$ \\
\hline $15: 00$ to $23: 59$ & & & & & & & $1.4(0.5-4.2)$ \\
\hline $2 \mathrm{LL}$ of the model & 500 & 476 & 427 & 415 & 304 & 194 & 188 \\
\hline Increment on $\chi^{2}$ & $130^{*}$ & $154^{\star}$ & $203^{*}$ & $213^{*}$ & $263^{*}$ & $243^{*}$ & $249^{*}$ \\
\hline
\end{tabular}

2LL of the model: log likelihood of the model. $* p<0.05$

In this public maternity hospital, age (20-34 years), primiparity, last delivery by cesarean, patient requesting a cesarean, cervical dilatation $<3 \mathrm{~cm}$ at admission, post-term gestational age, male attending obstetrician, and obstetrician on hospital duty $>24$ hours per week or with a private practice, and delivery during the day shift (9:00 am to 3:00 pm) were independent predictors of cesarean. On the other hand, signs of labor before leaving home, pre-term gestational age, oxytocin, and amniotomy were associated with decreased odds of cesarean.

Some limitations in this study must be considered. Compared to medical charts, most of the patients' self-reported information on obstetric history and adverse gestational events was valid. It is possible that questions such as those related to preference and requests for ce- sarean should be repeated at different moments during the gestation (see Potter et al. 5). Occasional changes of opinion (related to physical and emotional problems) could thus be monitored. This study did not include private patients (from private hospitals), who may have different characteristics, not susceptible to the proposed interventions.

As expected, various patient characteristics involved increased odds of cesarean section. Young women were more prone to cesareans than adolescents, suggesting that age is an independent predictor of type of delivery, in agreement with other Brazilian authors 11,21,22 who reported a similar association. In our study, the effect of age was partially explained by cervical dilatation at admission and use of oxytocin, indicating that both the stage of labor and its 
management may reduce the effect of age on the odds of cesarean. Still, even after adjusting for variables at all levels, the effect of age remained.

No association was found between mother's schooling and type of delivery. This can be explained by the relative socioeconomic homogeneity of these patients, also found by Freitas 11 . However, obstetric history strongly influenced type of delivery. The association between primiparity and cesarean section was also found in Brazil by Janowitz et al. 21 and Barros et al. 23 . According to Freitas 11 (p. 154), the majority of obstetricians "considered primiparae less capable of dealing with the difficulties of labor".

The strong influence of previous cesarean on the odds of repeating the surgery was also observed by Freitas 11. Prior cesareans were among the principal medical indications of a cesarean in Brazilian studies based on hospital records 24 . In our study, this effect was only reduced when oxytocin was included in the model, suggesting that the way labor is managed can reduce the odds of subsequent cesareans. Although the literature reports excellent results with trial of labor 25,26 , this practice has still not been incorporated into Brazilian obstetric practice.

Regarding prenatal care characteristics, our study showed that women who had prenatal care and delivery in this same public maternity hospital had increased odds of cesarean, even after adjusting for age, obstetric history, and adverse gestational events. Thus, this association cannot be entirely explained by the patient's increased gestational risk, leaving one to speculate that the type of information and suggestions transmitted by health services during prenatal care may favor cesareans 11,22,27.

The effect of adverse gestational events decreased (losing statistical significance) after adjusting for cervical dilatation at admission, suggesting that hypertension may not be a motive for not attempting vaginal delivery 28 .

The declared preference for vaginal delivery expressed by most patients in our study is consistent with other Brazilian studies 5,11,12,13,14. Our study showed a positive association between preference for cesarean and delivery by cesarean.

An original result of our study, not identified in the literature consulted, relates to the importance of women's proper perception of labor signs when leaving home for the hospital, yielding significantly lower odds of cesarean. The effect was direct and was not explained by any of the other variables. Likewise, early admission (with cervical dilatation $<3 \mathrm{~cm}$ ) was one of the strongest predictors of cesarean. Freitas 11 argues that the patient's psychological status on arrival influences both the way they deal with labor and the obstetrician's decisions. Clement 29 agrees with the observation that early arrival at the maternity hospital can affect progress of labor. These results indicate the importance of prenatal orientation on typical signs of labor, enabling women to adequately recognize them and avoid coming to the maternity hospital too early.

In relation to management of labor, use of oxytocin was associated with decreased odds of cesarean, consistent with the findings by Freitas 11 . This result was not eliminated by adjusting for all other variables, suggesting that the decreased odds of using oxytocin in women submitted to cesarean occurred because the decision for cesarean had already been made, thus dispensing use of this medication.

The influence of obstetrician's characteristics on type of delivery appears to occur due to the variability in the perception of symptoms indicating the need for cesarean 11. In our study, cesareans were performed more frequently by male obstetricians, those with $>24$ hours/week on duty, or those with private practices. These characteristics may indicate a more interventionist profile for obstetricians subject to an excessive workload. This result is consistent with Freitas 11, who identified doctor-centered organization of obstetric practice with little teamwork and excessive workload as contributing factors to cesareans. Concerning the association between obstetrician's gender and type of delivery, female obstetricians in the public maternity hospital may be more sensitive to the influence of government policy to curb the cesarean rate, or they may have different jobs and/or less demanding work hours. This result deserves more in-depth qualitative research on such differences. Various studies indicate the effects of obstetrician's characteristics on type of delivery 10,11,30,31,32,33, but we found only two 34,35 with an independent association between male gender and increased odds of cesarean.

Our study showed increased odds of cesarean during some periods of the day. This result, with no apparent technical explanation, suggests that convenience of the team on duty influences type of delivery. Freitas 11 also observed the practice of speeding up delivery during the day in cases which could prove to be more protracted or prone to complications, in order to avoid dealing with them in the middle of the night.

These data reinforce the importance of avoiding early hospital admission, which could lead 
to an erroneous diagnosis of prolonged labor after a few hours. This could be accomplished through reorganization of prenatal care, with more frequent appointments scheduled toward the end of pregnancy and provision of adequate information on the signs of labor, as well as guaranteeing a vacancy in the maternity at the necessary time. Medical training in the use of the partogram could help reduce anxiety in both physicians and patients and lead to more adequate treatment.

\section{Resumo}

O Brasil apresenta uma das maiores proporções de cesáreas do mundo. Fatores contribuintes para este fenômeno incluem organização da prática obstétrica, atitudes dos obstetras, preferências e decisões das mulheres. Com o objetivo de identificar fatores associados à realização de cesáreas, foi realizado estudo de casocontrole em uma maternidade pública do Município do Rio de Janeiro. Incluíram-se 231 partos por cesárea (casos) e 230 partos vaginais (controles). Utilizou-se análise multivariada com regressão logística, as variáveis foram incluídas no modelo obedecendo à ordem hierárquica definida em modelo conceitual. Fatores associados à maior chance de cesárea: primiparidade; idade 20-34 anos; último parto por cesárea; dilatação cervical < $3 \mathrm{~cm}$ na admissão; preferência da mulher por cesárea; horário diurno; parto realizado por obstetra do sexo masculino; obstetra que trabalha mais de 24 horas semanais de plantão; obstetra com consultório particular; hipertensão; apresentação fetal nãocefálica; e idade gestacional > 41 semanas. Fatores associados à menor chance de cesárea: prematuridade; sinais de trabalho de parto ao sair de casa; uso de ocitocina e amniotomia. Propostas de modificação nos fatores estudados podem contribuir para redução da proporção de cesáreas.

Cesárea; Parto; Maternidades
Policies instituting trial of labor for women with previous cesareans are also important for reducing the cesarean rate. This would require increased medical training as well as more accurate information during prenatal care for women with previous cesareans. Changes in medical education (to consider delivery a physiological rather than pathological event) could reduce the fear of unexpected situations during labor instead of prioritizing the degree of medical control offered by the surgical procedure.

\section{Contributors}

E. D'Orsi contributed to the design, planning, data collection, analysis, and interpretation, and drafting of the paper. D. Chor participated in the analysis, data interpretation, drafting of the paper, critical review of the content, and approval of the paper's final version. K. Giffin coordinated the research, participated in the design, planning, and approval of the paper's final version. A. Angulo-Tuesta participated in the research coordination, design, planning, and data collection, analysis, and interpretation. G. P. Barbosa, A. S. Gama, and A. C. Reis participated in the design, planning, and data collection, analysis, and interpretation.

\section{References}

1. Departamento de Informação e Informática do SUS. Sistema de Informações de Nascidos Vivos. http://www.datasus.gov.br (accessed on 15/Jul/ 2003).

2. Salinas HP, Carmona SG, Albornoz JV, Veloz PR, Terra RV, Marchant RG, et al. Se puede reducir el índice de cesárea? Experiencia del Hospital Clínico de la Universidad de Chile. Rev Chil Obstet Ginecol 2004; 69:8-13.

3. Yazlle ME, Rocha JS, Mendes MC, Patta MC, Marcolin AC, Azevedo GD. Incidência de cesáreas segundo fonte de financiamento da assistência ao parto. Rev Saúde Pública 2001; 35:202-6.

4. Duarte EC, Schneider MC, Paes-Souza R, Ramalho WM, Sardinha LMV, Silva Jr. JB, et al. Epidemiologia das desigualdades em saúde no Brasil: um estudo exploratório. Brasília: Organização PanAmericana da Saúde; 2002. 
5. Potter JE, Berquó E, Perpétuo IHO, Leal OF, Hopkins K, Souza MR, et al. Unwanted caesarean sections among public and private patients in Brazil: prospective study. BMJ 2001; 323:1155-8.

6. D'Orsi E, Carvalho MS. Perfil de nascimentos no Município do Rio de Janeiro: uma análise espacial. Cad Saúde Pública 1998; 14:367-79.

7. Barros FC, Vaughan JP, Victora CG. Why so many caesarean sections? The need for a further policy change in Brazil. Health Policy Plan 1986; 1:19-29.

8. Carvalho ML. Mortalidade neonatal e aspectos da qualidade da atenção à saúde na Região Metropolitana do Rio de Janeiro em 1986/87 [Dissertação de Mestrado]. Rio de Janeiro: Escola Nacional de Saúde Pública, Fundação Oswaldo Cruz; 1993.

9. Porreco RP, Thorp JA. The cesarean birth epidemic: trends, causes and solutions. Am J Obstet Gynecol 1996; 175:369-74.

10. Berkowitz GS, Fiarman GS, Mojica MA, Bauman J, De-Regt RH. Effect of physician characteristics on the cesarean birth rate. Am J Obstet Gynecol 1989; 161:146-9.

11. Freitas PF. The epidemic of caesarean sections in Brazil, factors influencing type of delivery in Florianópolis, South Brazil [PhD Thesis]. London: London School of Hygiene and Tropical Medicine; 1999.

12. Hopkins K. Are Brazilian women really choosing to deliver by cesarean? Soc Sci Med 2000; 51:72540.

13. Béhague DP, Victora CG, Barros FC. Consumer demand for caesarean sections in Brazil: informed decision making, patient choice or social inequality? A population based birth cohort study linking ethnographic and epidemiological methods. BMJ 2002; 324:1-6.

14. Althabe F, Belizán JM, Villar J, Alexander S, Bergel E, Ramos S, et al. Mandatory second opinion to reduce rates of unnecessary caesarean sections in Latin America: a cluster randomised controlled trial. Lancet 2004; 363:1934-40.

15. Faúndes A, Cecatti JG. A operação cesárea no Brasil. Incidência, tendências, causas, conseqüências e propostas de ação. Cad Saúde Pública 1991; 7:150-73.

16. Fleiss JL. Statistical methods for rates and proportions. 2nd Ed. New York: John Wiley \& Sons; 1981.

17. Victora CG, Fuchs SC, Flores JA, Fonseca W, Kirkwood B. Risk factors for pneumonia among children in a Brazilian metropolitan area. Pediatrics 1994; 93:977-85.

18. Victora CG, Huttly SR, Fuchs SC, Olinto MTA. The role of conceptual frameworks in epidemiological analysis: a hierarquical approach. Int J Epidemiol 1997; 26:224-7.
19. Estebanez PE, Russel NK, Aguilar MD, Béland F, Zunzunegui MV. Woman, drugs and HIV/AIDS: results of a multicentre European study. Int J Epidemiol 2000; 29:734-43.

20. Barros FC, Victora CG, Horta BL. Ethnicity and infant health in Southern Brazil. A birth cohort study. Int J Epidemiol 2001; 30:1001-8.

21. Janowitz B, Nakakamura MS, Lins FE, Brown ML, Clopton D. Cesarean section in Brazil. Soc Sci Med 1982; 16:19-25.

22. Barros FC, Vaughan JP, Victora CG, Huttly S. Epidemic of caesarean sections in Brazil. Lancet 1991; 338:167-9.

23. Barros FC, Victora CG, Morris SS. Caesarean sections in Brazil. Lancet 1996; 347:839.

24. D'Orsi E, Chor D, Giffin K, Barbosa GP, AnguloTuesta AJ, Gama AS, et al. Factors associated with vaginal birth after cesarean in a maternity hospital of Rio de Janeiro. Eur J Obstet Gynecol Reprod Biol 2001; 97:152-7.

25. Rosen MG, Dickinson JC, Westhoff CL. Vaginal birth after cesarean: a meta-analysis of morbidity and mortality. Obstet Gynecol 1991; 77:465-70.

26. Harer WB. Vaginal birth after cesarean delivery: current status. JAMA 2002; 287:2627-30.

27. LoCicero AK. Explaining excessive rates of cesareans and other childbirth interventions: contributions from contemporary theories of gender and psychosocial development. Soc Sci Med 1993; 37:1261-9.

28. Enkin M, Keirse MJNC, Renfrew M, Neilson J. A guide to effective care in pregnancy \& childbirth. 2nd Ed. Oxford: Oxford Medical Publications; 1996.

29. Clement S. The caesarean experience. London: Pandora Press; 1991.

30. Goyert GL, Bottoms SF, Treadwell MC, Nehra PC. The physician factor in cesarean birth rates. $\mathrm{N}$ Engl J Med 1989; 320:706-9.

31. Signorelli C, Cattaruzza MS, Osborn JF. Risk factors for caesarean section in Italy: results of a multicentre study. Public Health 1995; 109:191-9.

32. Hueston WJ. Site-to-site variation in the factors affecting cesarean section rates. Arch Fam Med 1995; 4:346-51.

33. Poma PA. Effects of obstetrician characteristics on cesarean delivery rates. A community hospital experience. Am J Obstet Gynecol 1999; 180:136472.

34. Tussing AD, Wojtowycz MA. The effect of physician characteristics on clinical behavior: cesarean section in New York State. Soc Sci Med 1993; 37:1251-60.

35. Mitler LK, Rizzo JA, Horwitz SM. Physician gender and cesarean sections. J Clin Epidemiol 2000; 53:1030-5.

Submitted on 10/Mar/2005

Final version resubmitted on 09/Sep/2005

Approved on 27/Sep/2005 